\title{
40. PATTERNS OF SEDIMENT COMPACTION AT OCEAN DRILLING PROGRAM SITES 645, 646, AND 647, BAFFIN BAY AND LABRADOR SEA ${ }^{1}$
}

\author{
William H. Busch ${ }^{2}$
}

\begin{abstract}
With several exceptions, porosity and density measurements of sediments cored at Site 645 in Baffin Bay and Sites 646 and 647 in the Labrador Sea reveal compaction patterns typical of terrigenous sediments. Deviation from standard porosity trends is greatest at depths shallower than $\mathbf{3 5 0}$ meters below seafloor (mbsf). This depth range contains the greatest variability in porosity at the individual sites and the largest differences between the Leg 105 sites and other terrigenous sediment sections. Porosity variation in this range is attributed primarily to differences in sediment texture and composition. At greater depths, pressure is the dominant factor influencing compaction, and the patterns are more uniform. Sediments at Sites 645 and 646 parallel typical terrigenous sediment porosity profiles. The more rapid decrease of porosity at Site 647 probably reflects the greater age and diagenetic alteration of these sediments. Comparisons of porosity profiles for the three sites are based on laboratory-measured porosities corrected for sediment expansion. At Site 646 , the expansion correction procedure yields a porosity profile that closely matches a profile based on porosities estimated from the borehole sonic log.
\end{abstract}

\section{INTRODUCTION}

Drilling in Baffin Bay and the Labrador Sea during ODP Leg 105 provided the opportunity to examine factors influencing porosity-depth relationships in predominantly terrigenous sediments. The general relationship between porosity and depth for terrigenous and other marine sediments, documented in reviews by Meade (1966), Skempton (1970), Rieke and Chilingarian (1974), and Bryant et al. (1981), is that of decreasing porosity with increasing burial depth. Variations in patterns of porosity at the sites drilled in Baffin Bay and the Labrador Sea display aspects that closely match widely accepted compaction models for terrigenous sediments as well as features that differ from normally accepted models.

Four basic processes are responsible for the reduction of porosity with sediment burial: (1) mechanical compaction; (2) mechanical dissolution (pressure dissolution and grain deformation by fracture or plastic creep); (3) chemical dissolution and cementation; and (4) phase transformation of clay minerals (Addis and Jones, 1985). The first of these processes depends entirely on the applied stress system, the second process is a function of both the effective stress and time, and the latter two processes are strongly time dependent. The time-dependent processes are collectively referred to as "aging" by soils engineers. In the shallow part of the sedimentary section, typically $500 \mathrm{~m}$ or less (Berner, 1980), porosity reduction is dominated by mechanical compaction; that is, sediment dewatering that occurs as the continued accumulation of sediments increases the vertical stress and causes a rearrangement of the granular aggregate. At greater depths, deformation of sediment grains and chemical dissolution increase in importance as means of reducing porosity. The contribution of the aging mechanisms to the overall reduction of porosity and the point at which these mechanisms dominate the process are not well understood.

The objectives of this paper are (1) to compare porositydepth relationships at Site 645 in Baffin Bay with Sites 646 and

\footnotetext{
${ }^{1}$ Srivastava, S. P., Arthur, M., Clement, B., et al., 1989. Proc. ODP, Sci. Re-

sults, 105: College Station, TX (Ocean Drilling Program).
2 Department of Geology and Geophysics, University of New Orleans, New Orleans, LA 70148.
}

647 in the Labrador Sea (Fig. 1) and (2) to compare variations in porosity at the Leg 105 sites with those documented for other terrigenous sediment sequences. In addition, comparison of porosity-depth relationships will incorporate examination of methods that compensate for the effects of sediment expansion on laboratory-determined porosities.

\section{METHODS}

\section{Shipboard Porosity and Wet-Bulk Density Measurements}

This study is based on determinations of density and porosity for discrete core samples obtained at Sites 645,646 , and 647. Wet-bulk density and porosity were calculated from (wet and dry) weight and volume measurements conducted on "chunk" samples aboard ship. Details of the procedures for the gravimetric and volumetric measurements are described in Srivastava, Arthur, et al. (1987). A salt correction, outlined by Hamilton (1971), was applied to the computation of density and porosity.

Continuous profiles of wet-bulk density were determined for core sections using the Gamma Ray Attenuation Porosity Evaluator (GRAPE). Principles and methodology for operating this device are described by Boyce (1976). Wet-bulk density values determined by the GRAPE were used to check anomalous porosity values from the gravimetric and volumetric measurements. Anomalous values not supported by the GRAPE measurements were discarded.

\section{Porosity Data from Borehole Logs}

All three sites drilled during Leg 105 were logged to some extent. Operational details of the logging program are described in Srivastava, Arthur, et al. (1987). The most complete section logged was at Site 646, where $547 \mathrm{~m}$ of the total $767 \mathrm{~m}$ penetrated was logged. The interval logged at this site is from 205 to 752 mbsf. At Site 645 , of the total penetration of $1147 \mathrm{~m}$, a $218-\mathrm{m}$ section was logged, and at Site 647 , logs were generated for $146 \mathrm{~m}$ of the $699 \mathrm{~m}$ of sediment drilled.

One use of the borehole logs was to provide an estimate of the in-situ porosity, which then was compared with laboratory-determined porosities to provide a means for evaluating sediment expansion that occurs as cores are removed from the borehole. Because of the fragmentary sections logged at Sites 645 and 647 , comparison of porosity determinations from logs and laboratory measurements was limited to Site 646. Types of logs generated at Site 646 that are useful for estimating porosity include (1) resistivity log, obtained with the dual induction tool (DIL); (2) neutron log (CNT-G); and (3) long-spaced sonic log (LSS). The LSS log was used for this initial comparison of log porosity with laboratory-determined porosity because simple relationships exist for estimating porosity from sonic velocity (Hamilton, 1978). Estimation of 


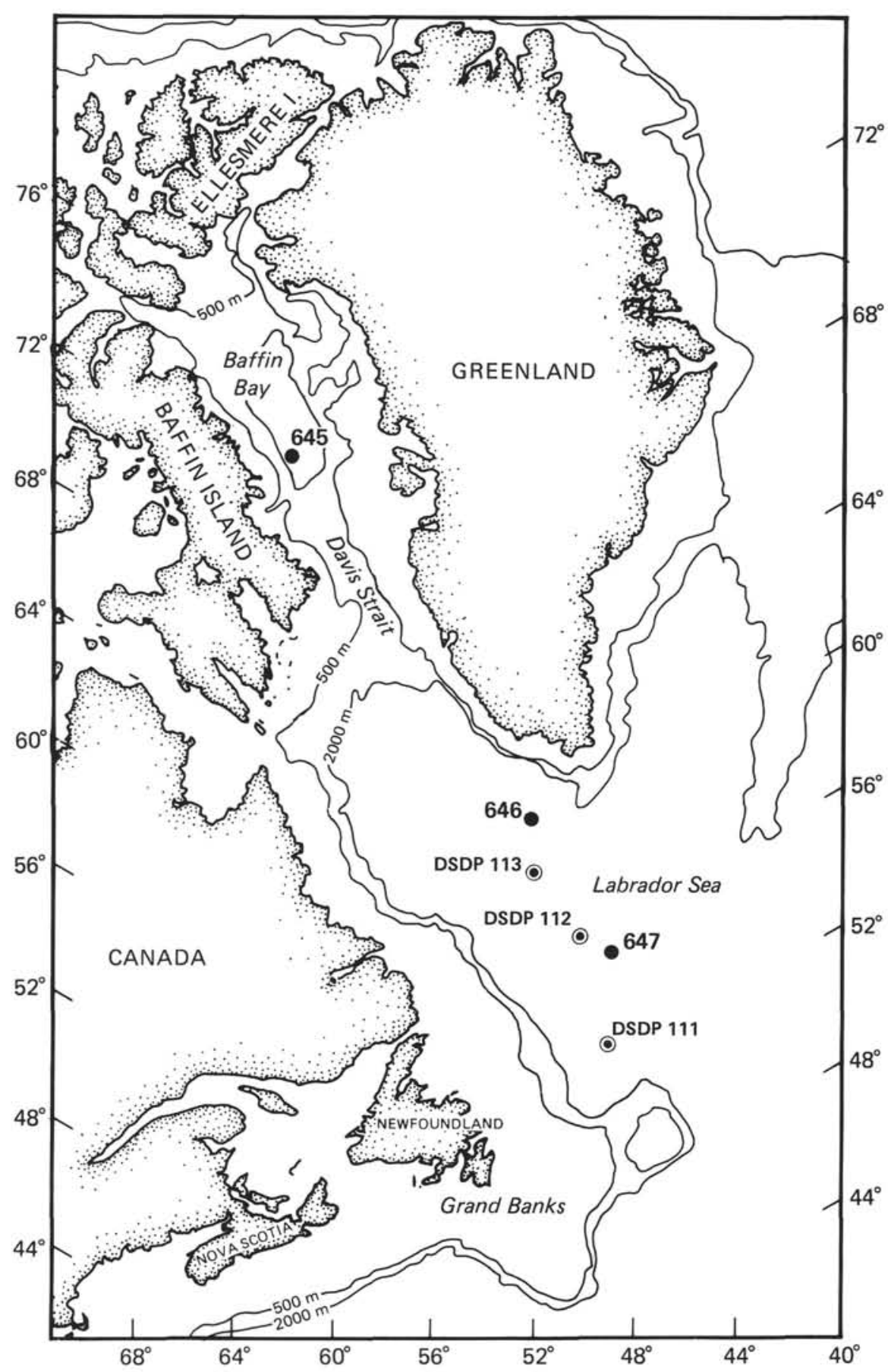

Figure 1. Location map for Leg 105 sites.

porosity from sonic logs is also independent of calibration with corebased porosity measurements or other borehole logs.

\section{ANALYTICAL TECHNIQUES AND RESULTS}

\section{Laboratory-Measured Porosity-Depth Profiles}

Plots of porosity vs. depth for Sites 645, 646, and 647 are shown in Figures 2, 3, and 4, respectively. In addition to the core-measured porosities, exponential lines fit through the data are shown on the plots for comparison among the sites (Table 1). These lines represent a best-fit to the equation,

$$
\phi=\phi_{o} e^{(-a z)},
$$

where $\phi=$ the estimated porosity $(\%), z=$ sub-bottom depth (in meters), and $\phi_{o}$ and $a$ are constants that vary with sediment type and burial history.

Equation 1 (Athy's Law) was proposed by Athy (1930) to represent the porosity-depth relationship in shales and is a widely used expression in applied geophysics. It is an empirically established expression, although a mathematical-physical derivation verifying the relationship was provided by Korvin (1984). In strict usage, Athy's Law describes the final equilibrium state of fine-grained sediments after water has migrated vertically upward. Interbedded sand and mud can result in significant horizontal migration of water, and the exponential compaction law may not strictly apply (Magara, 1976). 


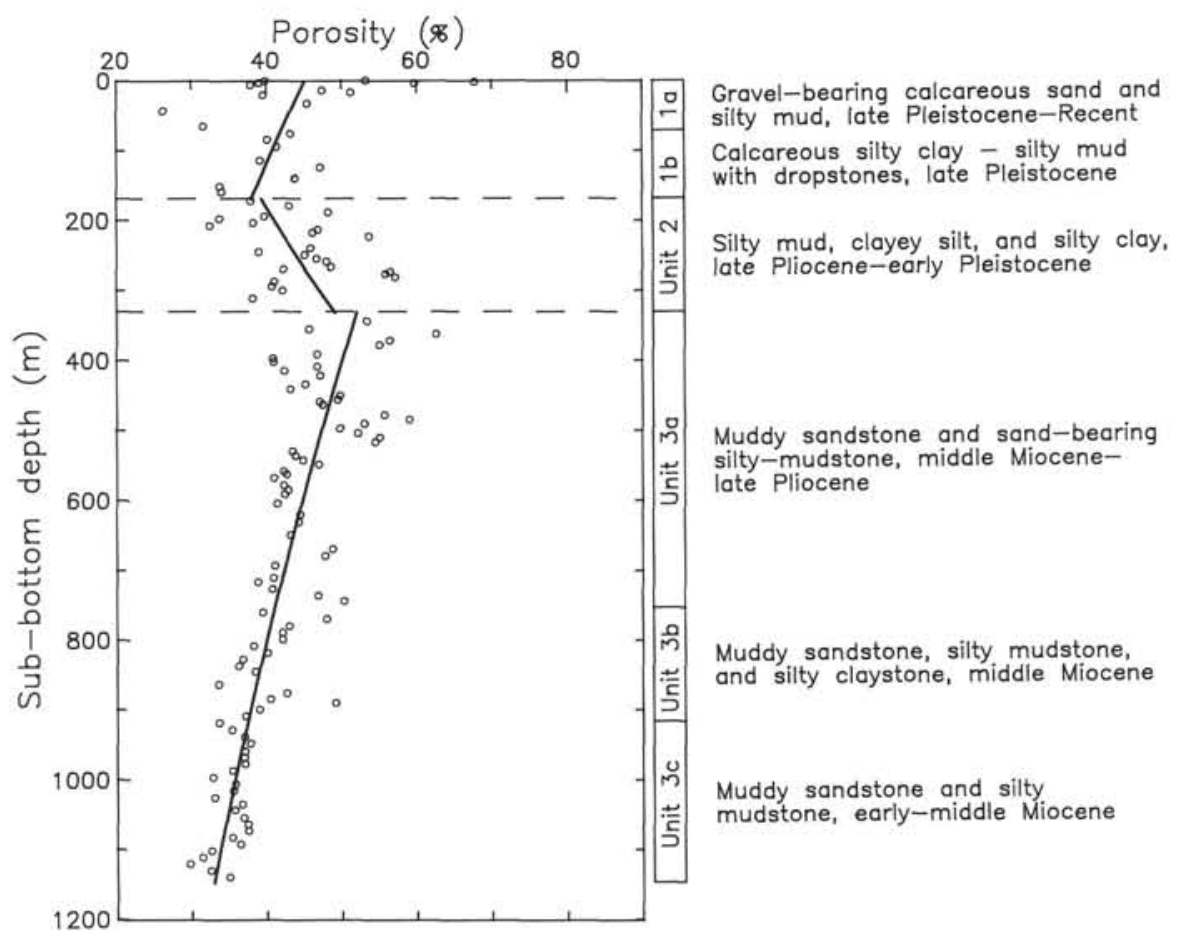

Figure 2. Porosity vs. depth as measured for core samples at Site 645. Dashed lines separate intervals over which best-fit lines were derived. Coefficients for equations for the lines are listed in Table 1. Lithologic units are defined in Srivastava, Arthur, et al. (1987).

The profiles of porosity vs. depth at Sites 645, 646, and 647 were divided into segments for purposes of determining the best-fit exponential lines (Figs. 2, 3, and 4). The reason for this division is that all sediments compact and dewater on burial; but because of physical and chemical differences in the matrix, different sediments compact at different rates with respect to effective overburden pressure and time. Segmentation of the profiles was based on (1) obvious differences in lithology and (2) distinct changes in the porosity-depth trends.

\section{Site 645}

Site 645 lies on the continental slope off southern Baffin Island at a water depth of $2018 \mathrm{~m}$. A thick sequence of terrigenous sediments of Miocene to Holocene age was recovered at this site. The sediment column is divided into three lithologic units (Fig. 2). Lithologic Unit I (0-168.1 mbsf) consists of calcareous muddy sands and gravel-bearing muddy sands, calcareous silty muds, and silty clays deposited predominantly by icerafting. Lithologic Unit II (168.1-335 mbsf) consists of silty mud, clayey silt, and silty clays that also were deposited by icerafting, with possible weak modification by slow-moving bottom currents. Lithologic Unit III (335-1147.1 mbsf) is composed of homogeneous, poorly sorted muddy sands and sandbearing silty muds. Dominant depositional processes changed from bottom currents, during early phases of deposition of the unit, to a mixture of waning bottom currents, high-density turbidity currents, and ice rafting, during later stages of deposition.

The vertical porosity profile exhibits low and variable porosity in near-surface sediments (Fig. 2). High variability can be seen by porosities ranging from $61 \%$ to $38 \%$ in the first $5 \mathrm{~m}$ below the seafloor. The overall pattern of porosity variation at this site is one of top and bottom intervals of decreasing porosity with depth, separated by a middle interval of increasing porosity with depth (Fig. 2). Porosity at the top of the lowermost interval is greater than the porosity of modern sediments on the sea- floor. The limits for the best-fit lines were chosen to coincide with the lithologic unit boundaries.

A general characteristic of all three Leg 105 sites is that porosity exhibits the greatest variability near the seafloor and becomes more uniform with depth (Figs. 2, 3, and 4). At Site 645, porosity varies more in the deeper part of the section than at the other two sites. Seismic lines near Site 645 display faults that cut the strata of Lithologic Unit III (Srivastava, Arthur, et al., 1987). Possibly, these faults are more permeable conduits that produce localized drainage in the sediments and, consequently, a more variable porosity profile. Sediments at Site 645 also display the highest sand content and the most variable sand-siltclay ratios of the three sites (Srivastava, Arthur, et al., 1987), which contributes to the greater variations in porosity.

\section{Site 646}

Site 646 is located on the northwestern flank of the Eirik Ridge in the northeastern Labrador Sea at a water depth of 3451 $\mathrm{m}$. Fine-grained terrigenous sediments of late Miocene to Holocene age were drilled at this site. The sediment column is divided into two lithologic units (Fig. 3). Lithologic Unit I (0$236.1 \mathrm{mbsf}$ ) contains silty clays, clayey silts, and silty muds with variable amounts of scattered gravel-sized rock fragments. Depositional processes that were recognized for this unit include ice rafting, bottom currents, low-concentration turbidity currents, and dilute offshelf turbid flows. Lithologic Unit II (236.1-766.7 mbsf) consists of silty clay(stone), clayey silt(stone), clay(stone), and nannofossil silty clay(stone) and clayey silt(stone), which were interpreted as contourite or drift deposits.

There is an overall decrease in porosity with depth at Site 646 , with surface porosity values ranging from $80 \%$ to $75 \%$. Based on a sharp decrease in porosity (15\%) at $335 \mathrm{mbsf}$ (Fig. 3 ), the vertical profile at this site is divided into two segments.

\section{Site 647}

Site 647 is located $100 \mathrm{~km}$ south of the Gloria Drift in the southern Labrador Sea at a water depth of 3862 m. Early Eo- 


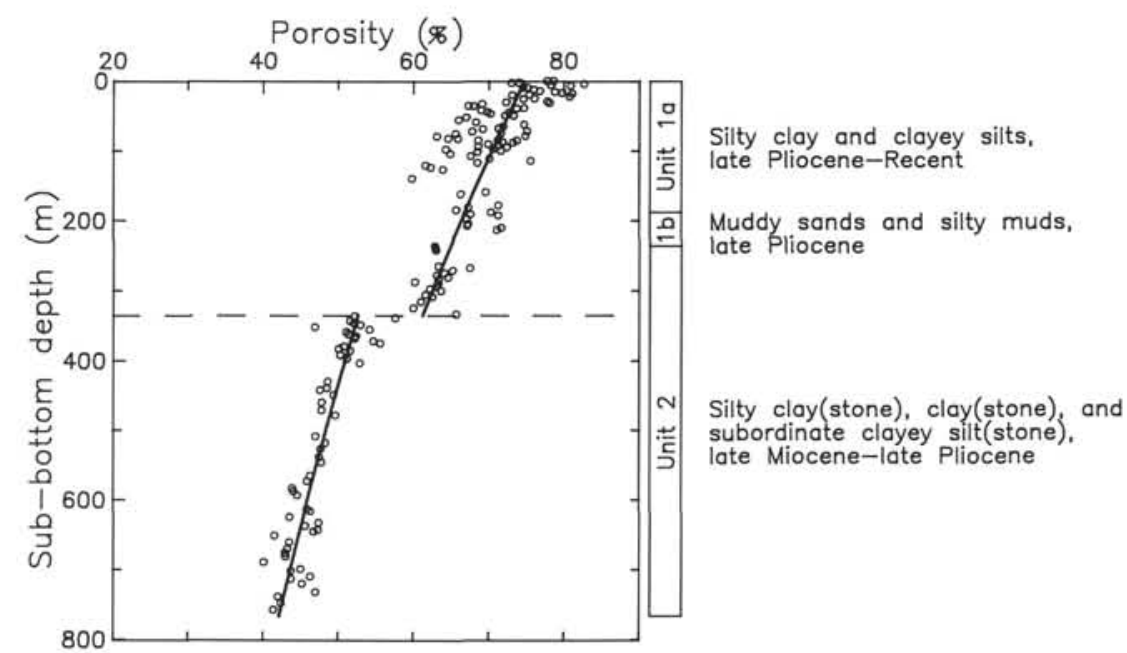

Figure 3. Porosity vs. depth as measured for core samples at Site 646. Dashed lines separate intervals over which best-fit lines were derived. Coefficients for equations for the lines are listed in Table 1. Lithologic units are defined in Srivastava, Arthur, et al. (1987).

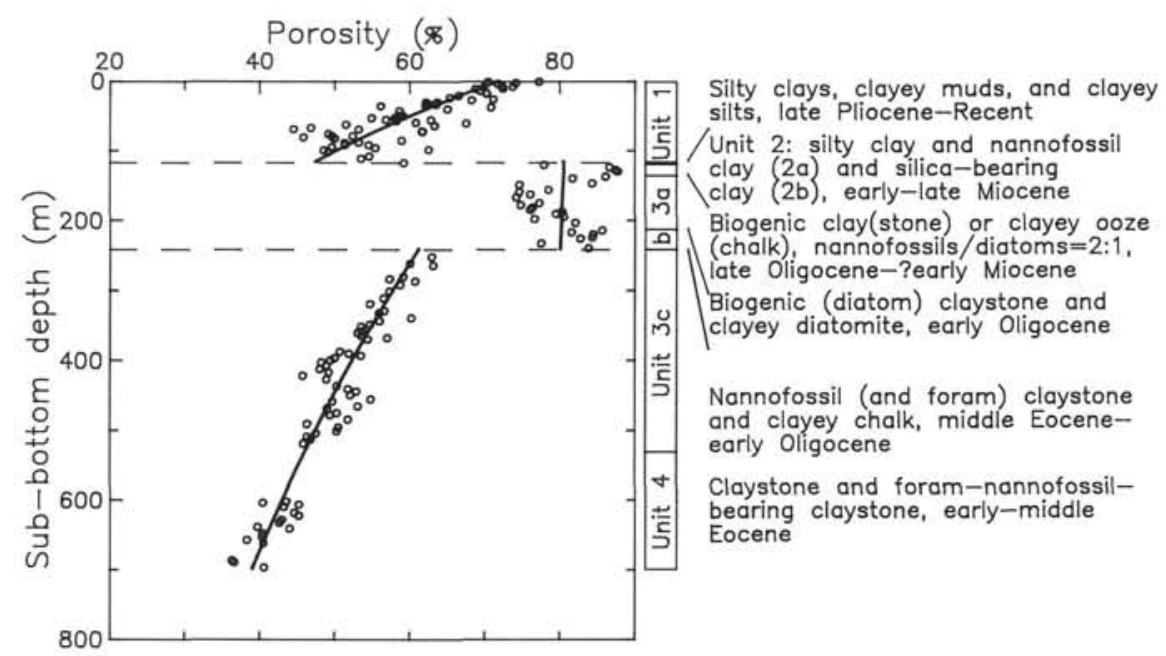

Figure 4. Porosity vs. depth as measured for core samples at Site 647. Dashed lines separate intervals over which best-fit lines were derived. Coefficients for equations for the lines are listed in Table 1. Lithologic units are defined in Srivastava, Arthur, et al. (1987).

cene to Holocene terrigenous and biogenic sediments were recovered at this site. The sediment column is divided into four lithologic units (Fig. 4). Major lithologies of Unit I (0-116 mbsf) are silty clays, clayey muds, and clayey silts having variable amounts of biogenic components and scattered gravel-sized rock fragments. Ice rafting and winnowing by bottom currents have been identified as processes that deposited these sediments. Lithologic Unit II (116-135.4 mbsf) is a condensed section ranging in age from early to late Miocene. The unit contains silty clay, nannofossil clay, and brown, yellow, and green clay. Lithologic Unit III (135.4-530.3 mbsf) is made up of biogenic (diatom and nannofossil) clays and clayey oozes deposited by hemipelagic sedimentation; clay was transported to the site by weak bottom currents. Lithologic Unit IV (530.5-699 mbsf) consists of claystones or foraminifer- and nannofossil-bearing claystones deposited by hemipelagic sedimentation.

The porosity-depth profile at Site 647 is divided into three segments (Fig. 4). The top interval coincides with lithologic Unit I. Porosity is between $77 \%$ to $72 \%$ at the surface, with a sharp decrease to the base of Unit I. The middle segment of the profile, which extends from the top of lithologic Unit II to the base of Subunit IIIB (241.1 mbsf), contains sediments with the highest porosities at the site $(88 \%$ to $74 \%)$. Porosity decreases more or less uniformly in Subunit IIIC and Unit IV. The porosity-depth gradient in this interval is less than that in Lithologic Unit I, and porosity at the top of Subunit IIIC is higher than porosity at the base of Unit I.

\section{Estimation of Sample Rebound}

It is generally accepted that laboratory density and porosity measurements of core samples do not truly represent in-situ values of these parameters (Hamilton, 1976). The basis for the discrepancy between laboratory measurements and in-situ values is the increased volume that accompanies removing a sample from the pressure of overlying sediments. The procedure for estimating sample rebound at Sites 645,646 , and 647 involved two steps: (1) conversion of porosity-depth profiles to porosity-effective overburden pressure profiles and (2) applying relation- 
Table 1. Coefficients of best-fit lines for porosity vs. depth and porosity vs. effective overburden pressure.

\begin{tabular}{|c|c|c|c|c|c|c|c|}
\hline \multirow[b]{2}{*}{ Site } & \multirow[b]{2}{*}{ Interval } & \multicolumn{2}{|c|}{$\begin{array}{l}\text { Laboratory } \\
\text { porosity- } \\
\text { depth }\end{array}$} & \multicolumn{2}{|c|}{$\begin{array}{l}\text { In-situ porosity- } \\
\text { effective } \\
\text { overburden } \\
\text { pressure }\end{array}$} & \multicolumn{2}{|c|}{$\begin{array}{l}\text { In-situ } \\
\text { porosity- } \\
\text { depth }\end{array}$} \\
\hline & & $\begin{array}{c}\phi_{o} \\
(\%)\end{array}$ & $\begin{array}{c}a \times 10^{-4} \\
\left(\mathrm{~m}^{-1}\right)\end{array}$ & $\begin{array}{l}\phi_{o} \\
(\%)\end{array}$ & $\begin{array}{c}a \times 10^{-5} \\
\left(\mathrm{kPa}^{-1}\right)\end{array}$ & $\begin{array}{l}\phi_{o} \\
(\%)\end{array}$ & $\begin{array}{c}a \times 10^{-4} \\
\left(\mathrm{~m}^{-1}\right)\end{array}$ \\
\hline \multirow[t]{3}{*}{645} & Top & 45.0 & 10.3 & 44.9 & 16.6 & 45.0 & 18.0 \\
\hline & Middle & 31.2 & -13.6 & 28.3 & -10.9 & 28.9 & -10.4 \\
\hline & Bottom & 62.5 & 5.65 & 51.7 & 6.17 & 52.0 & 6.11 \\
\hline \multirow[t]{4}{*}{646} & Top & 74.5 & 5.96 & 74.0 & 13.7 & 74.8 & 8.70 \\
\hline & Bottom & 62.4 & 5.18 & 54.7 & 8.13 & 61.3 & 8.32 \\
\hline & Bottom & & & & & & \\
\hline & (sonic log) & & & & & 63.4 & 8.30 \\
\hline \multirow[t]{3}{*}{647} & Top & 72.1 & 36.1 & 70.5 & 54.2 & 72.3 & 40.1 \\
\hline & Middle & 81.2 & 0.565 & 81.2 & 3.47 & 80.4 & 1.56 \\
\hline & Bottom & 77.6 & 9.83 & 68.9 & 15.4 & 82.7 & 14.8 \\
\hline \multirow[t]{3}{*}{345} & Top & & & 65.8 & 113 & & \\
\hline & Middle & & & 105 & 54.1 & & \\
\hline & Bottom & & & 74.6 & 21.4 & & \\
\hline
\end{tabular}

Note: coefficients are derived from the equations: $\phi=\phi_{0} e^{(-a z)}$, where $z=$ meters below seafloor and $\phi=\phi_{o} e^{(-a P)}$, where $P=$ effective overburden pressure in kiloPascals. In-situ porosities are derived from the laboratory porosities by correcting for sample rebound.

ships derived by Hamilton (1976) to estimate expansion expected for a given overburden pressure. Relationships developed by Hamilton (1976) for estimating rebound are presented in final form as equations where depth is the independent variable, but are derived from porosity-overburden pressure relationships. Although simpler, the depth-rebound relationships were not used for estimating sample expansion at the Leg 105 sites because of the variable lithology and range of density gradients, particularly at Sites 645 and 647. In addition, conversion of porosity-depth profiles to porosity-effective overburden pressure profiles facilitates comparison of the sediment response with increasing overburden, based on the assumption that the observed porosity represents an equilibrium condition between the overburden pressure and the sediment framework maintaining the pore volume (Engelhardt, 1977).

Effective overburden pressure $(P)$ was calculated according to the equation,

$$
\mathrm{P}=\Sigma\left[\left(\rho_{b w n}+\rho_{b w n-1}\right) / 2-\rho_{w}\right] g\left(z_{n}-z_{n-1}\right),
$$

where $z_{n-1}$ and $z_{n}=$ the depths of successive core samples, $\rho_{b w}$ $=$ wet-bulk density $\left(\rho_{b w n-1}\right.$ and $\rho_{b w n}=$ wet-bulk densities of successive samples), $\rho_{w}=$ density of pore fluid (assumed to be $1.04 \mathrm{~g} / \mathrm{cm}^{3}$ ), and $\mathrm{g}=$ acceleration of gravity. Porosity variation as a function of effective overburden pressure at Sites 645,646 , and 647 is shown in Figures 5, 6, and 7, respectively. For simplicity, the porosity-effective overburden pressure profiles are shown only as the best-fit exponential lines through the data. These lines were derived to fit the equation,

$$
\phi=\phi_{o} e^{(-a P)} .
$$

Hamilton (1976) developed relationships for estimating porosity rebound for five deep-sea sediment types: terrigenous sediments, calcareous ooze, diatomaceous ooze, radiolarian ooze, and pelagic clay. The terrigenous-sediment relationship for estimating rebound was used at all depths at all three sites, with the exception of the interval at 116-241.1 mbsf at Site 647, for which the diatomaceous-ooze relationship was used. Selection of the general sediment-rebound relationship was based on the magnitude of porosity and the shape of the porosity-depth profile.

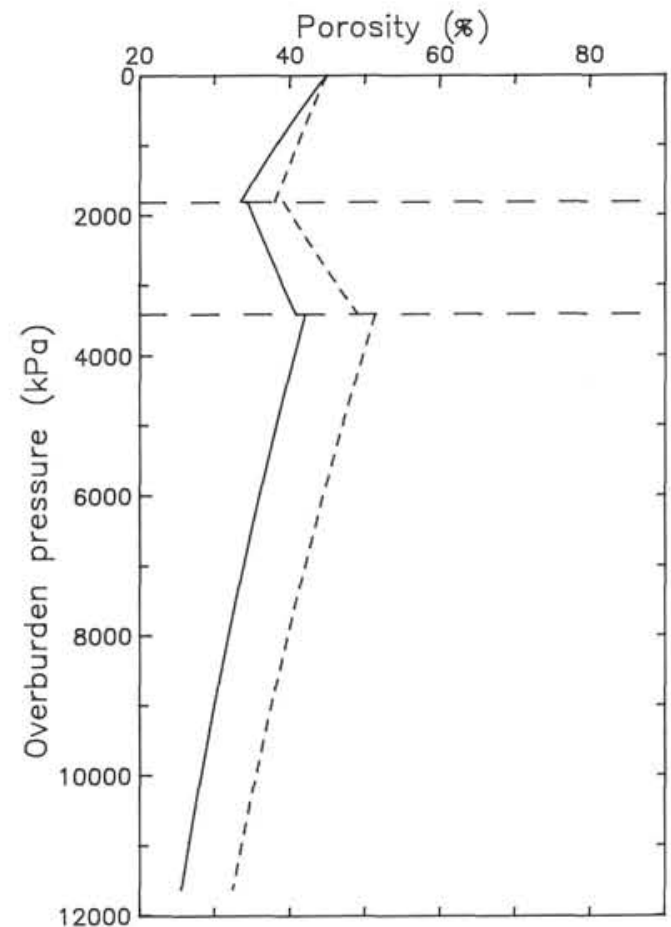

Figure 5. Porosity vs. effective overburden pressure at Site 645. Dashed lines represent best-fit lines for laboratory-determined porosity. Solid lines represent best-fit lines for rebound-corrected porosity data. Coefficients for equations for the rebound-corrected lines are listed in Table 1.

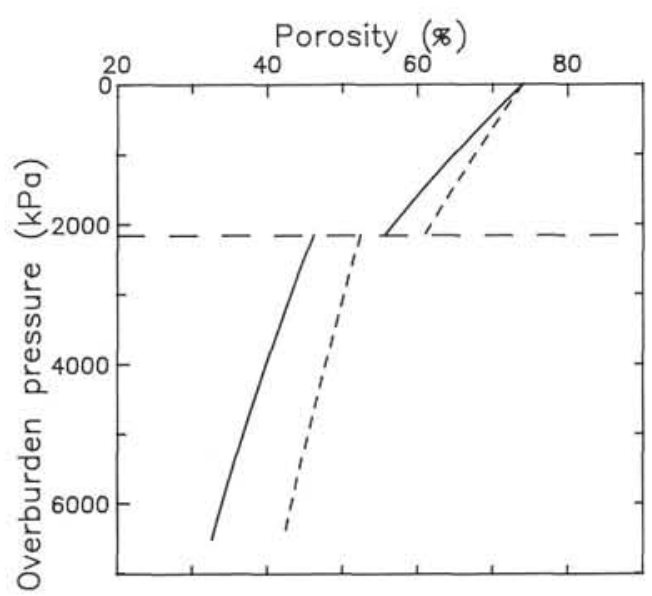

Figure 6. Porosity vs. effective overburden pressure at Site 646. Dashed lines represent best-fit lines for laboratory-determined porosity. Solid lines represent best-fit lines for rebound-corrected porosity data. Coefficients for equations for the rebound-corrected lines are listed in Table 1.

Estimating expansion of terrigenous sediments involved the use of relationships for three pressure ranges. These relationships and ranges were not specified by Hamilton (1976) but were derived from estimated rebound, depth, and density data provided by him. Equations used for estimating the rebound of terrigenous sediments are as follows:

1. $0-4950 \mathrm{kPa}$,

$$
\begin{aligned}
\phi_{r}= & -1.90 \times 10^{-11} P^{3} \\
& -1.00 \times 10^{-7} P^{2}+2.88 \times 10^{-3} P .
\end{aligned}
$$




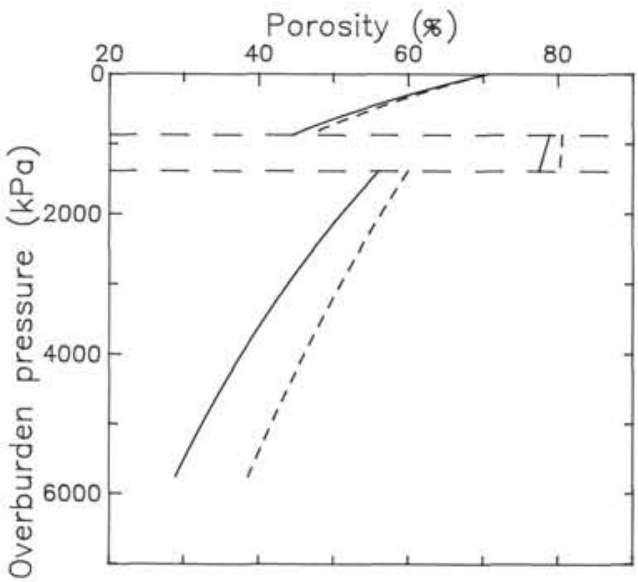

Figure 7. Porosity vs. effective overburden pressure at Site 647. Dashed lines represent best-fit lines for laboratory-determined porosity. Solid lines represent best-fit lines for rebound-corrected porosity data. Coefficients for equations for the rebound-corrected lines are listed in Table 1.

2. $4950-9625 \mathrm{kPa}$,

$$
\begin{aligned}
\phi_{r}= & 3.32 \times 10^{-12} P^{3}+2.68 \times 10^{-8} P^{2} \\
& -1.43 \times 10^{-3} P+15.5 .
\end{aligned}
$$

3. Greater than $9625 \mathrm{kPa}$,

$$
\phi_{r}=7.2 \text {, }
$$

where $\phi_{r}=$ rebound in porosity (in percent) and $P=$ effective overburden pressure (in $\mathrm{kPa}$ ).

The relationship derived by Hamilton (1976) for estimating the rebound of diatomaceous sediments (converted to SI units) is

$$
\phi_{r}=2.00 \times 10^{-3} P .
$$

Results of subtracting the estimated porosity rebound from porosities measured using core samples are shown in Figures 5, 6, and 7.

\section{Sonic Log Porosity Estimation-Site 646}

In-situ porosity at Site 646 was also estimated using data from the LSS log and the relationships between sonic velocity and wet-bulk density provided by Hamilton (1978). Hamilton furnished relationships that apply to estimating bulk density of three different categories of terrigenous sediments: (1) seafloor sediments, (2) soft sediments ( $0-500 \mathrm{mbsf})$, and (3) average mudstones and shales (greater than $500 \mathrm{mbsf}$ ). The latter two relationships were used for estimating bulk density from the LSS $\log$, but instead of depth criteria for selecting which relationship to use, selection was based on the measured velocity. Equations used for estimating wet-bulk density are as follows:

1. Soft sediments $\left(V_{p}<2 \mathrm{~km} / \mathrm{s}\right)$,

$$
\rho_{b w}=1.135 V_{p}-0.190 \text {. }
$$

2. Mudstones and shales $\left(V_{p}>2 \mathrm{~km} / \mathrm{s}\right)$,

$$
\rho_{b w}=-0.080 V_{p}^{2}+7.440 V_{p}+0.917 \text {, }
$$

where $V_{p}=$ sonic velocity (in $\mathrm{km} / \mathrm{s}$ ). The velocity value, $2 \mathrm{~km} /$ $\mathrm{s}$, chosen as a criterion for selecting which density-velocity rela- tionship to use, represents the approximate point at which Equations 8 and 9 intersect. A velocity criterion was used because it more accurately represents the physical state of the sediments than does an arbitrary depth criterion.

Porosity was calculated from estimated bulk-density values using the relationship,

$$
\phi=\left(\rho_{s}-\rho_{b w}\right) /\left(\rho_{s}-\rho_{w}\right),
$$

where $\rho_{s}=$ grain density. Average values of grain density measured for the intervals 205 to $335 \mathrm{mbsf}\left(2.770 \mathrm{~g} / \mathrm{cm}^{3}\right)$ and 335 to $758 \mathrm{mbsf}\left(2.791 \mathrm{~g} / \mathrm{cm}^{3}\right)$ were used for calculating porosity. Porosities estimated from the LSS log at Site 646 along with an exponential line fit through data for the 335 to $758 \mathrm{mbsf}$ depth range are shown in Figure 8. A best-fit line was not generated for the top interval at Site 646 because of the lack of logging data above 205 mbsf. In addition to the borehole data, Figure 8 shows lines representing exponential fits for the corrected porosity-depth data. Agreement among the porosity estimates for the two independent data sets is good. For the bottom interval, " $a$ " coefficients for the corrected-porosity and sonic-estimate relationships are nearly equal (Table 1), and the best-fit lines differ by only $1.0 \%$ to $1.5 \%$.

\section{Age-Depth Relationships}

Time-related factors affect sediment compaction by influencing the initial sediment porosity, rate of dewatering, and extent of development of "aging" processes. General aspects of the sediment age relationships at the Leg 105 sites follow. Sediments recovered at Site 645 display the highest sedimentation rates $(135 \mathrm{~m} / \mathrm{m} . \mathrm{y}$.) and greatest range in rates $(28$ to $135 \mathrm{~m} / \mathrm{m} . \mathrm{y}$.) (Fig. 9). Sedimentation rates are more uniform at Site 646, where the rates vary between 73 and $125 \mathrm{~m} / \mathrm{m}$.y. for most of the section. Site 647 displays the lowest sedimentation rates, 2.1 to $36 \mathrm{~m} / \mathrm{m} . \mathrm{y}$, and significant unconformities at (1) $116 \mathrm{mbsf}$, upper Pliocene (2.5 Ma) to upper Miocene (5.6 Ma); (2) $119 \mathrm{mbsf}$, upper Miocene (8.6 Ma) to lower Miocene (17.5 Ma); and (3) $135 \mathrm{mbsf}$, lower Miocene (22.5 Ma) to upper Oligocene (29.5 $\mathrm{Ma})$.

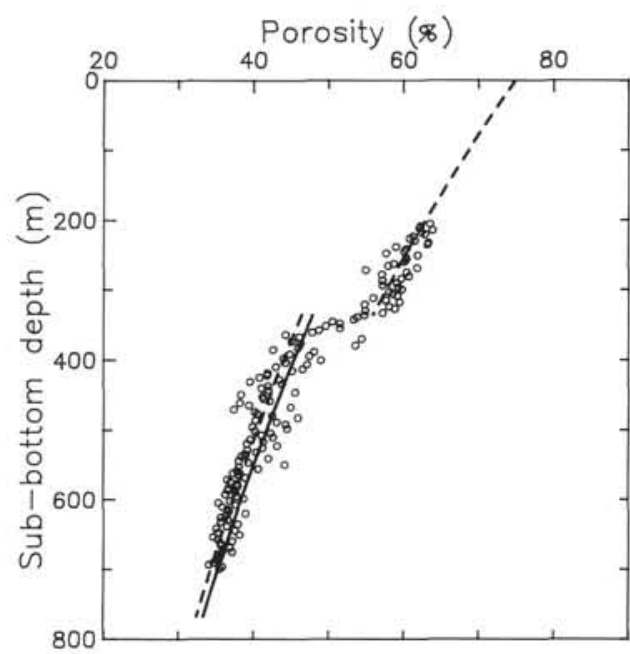

Figure 8. Porosity derived from LSS borehole log vs. depth at Site 646. Because of the log data density only every tenth point is shown. The solid line represents the best-fit line through log-estimated porosity for the 335-758 mbsf interval. Dashed lines represent best-fit lines for laboratory-measured porosity corrected for estimated rebound. Coefficients for equations for the lines are listed in Table 1. 


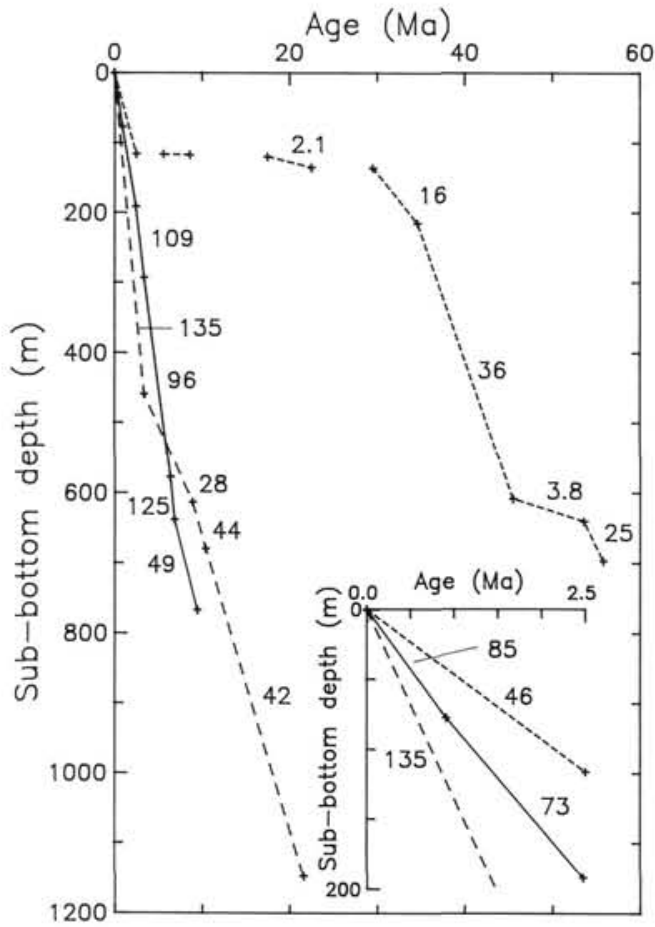

Figure 9. Sediment age vs. depth for Site 645 (long dashes), Site 646 (solid line), and Site 647 (short dashes). Numbers adjacent to lines are interval sedimentation rates (in m/m.y.). Ages are from biostratigraphic and magnetostratigraphic data (Srivastava, Arthur, et al., 1987).

\section{DISCUSSION}

\section{Compaction Patterns at Baffin Bay and Labrador Sea Sites}

Porosity-effective overburden pressure plots reflect differences in sediment response to burial beneath increasing sediment thicknesses at Sites 645, 646, and 647 (Fig. 10). The largest porosity differences among the sites are displayed at effective overburden pressures of less than $3000 \mathrm{kPa}$. Much of the variation of compaction patterns within this pressure range can be attributed to differences in sediment texture and composition.

At Site 645 , the porosity of near-surface sediments ranges from $40 \%$ to $50 \%$. This range is less than reported average porosities for surface terrigenous deep-sea sediments and is more typical of sandy sediments of continental shelf and slope environments (Hamilton, 1974). Porosity decreases with increasing pressure in the top interval at Site 645, lithologic Unit I, at a rate less than that of near-surface sediments at Sites 646 and 647 , which reflects the greater abundance of sand in this interval (Fig. 2). Sandy sediments are typified by low initial porosity and a slow decrease in volume during early stages of compaction (Meade, 1966; Engelhardt, 1977). The middle interval of the Site 645 porosity profile, lithologic Unit II, is unusual because porosity increases with increasing overburden pressure (Fig. 10). Porosity variation in this interval coincides with the transition from sedimentation dominated by turbidity currents and bottom currents in lithologic Unit III to deposition by ice rafting in lithologic Unit I. Factors associated with the change in depositional processes that could account for the upward decrease in porosity include a decrease in grain sorting and an increase in nonclay minerals in the clay-sized fraction. Sediment source is inferred to have shifted during the deposition of lithologic Unit II (Srivastava, Arthur, et al., 1987), and a change in clay mineralogy accompanying this shift may contribute to the porosity variation in Unit II.

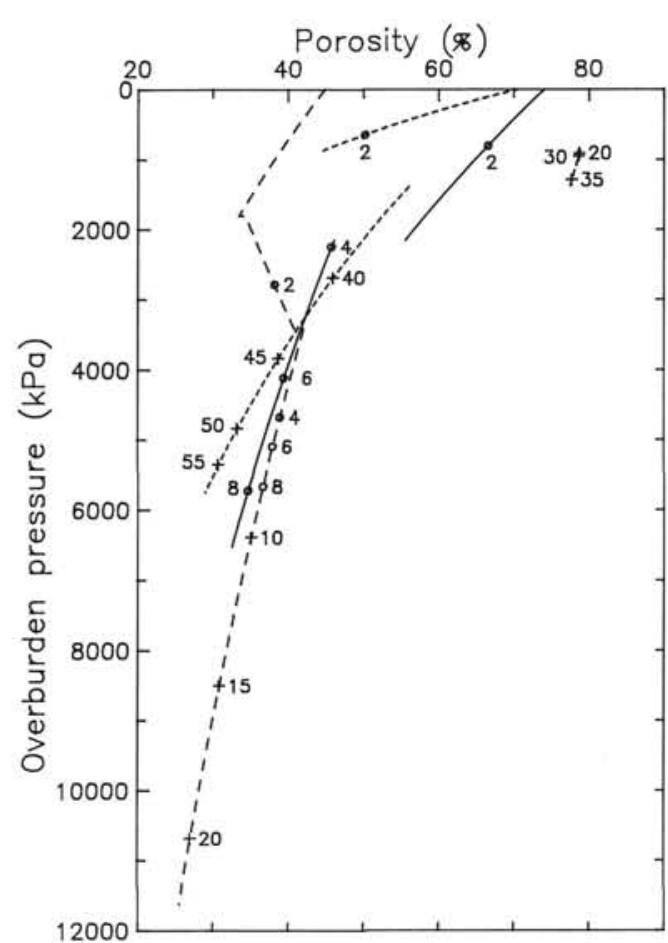

Figure 10. Porosity (rebound-corrected) vs. effective overburden pressure for Site 645 (long dashes), Site 646 (solid line), and Site 647 (short dashes). Profiles are exponential best-fit lines through the corrected porosity data. Sediment ages at corresponding overburden pressures are indicated by circles ( 2 m.y. intervals) and crosses ( 5 m.y. intervals over 10 Ma).

A sharp decrease in porosity at 335 mbsf (equivalent to 2150 $\mathrm{kPa}$ effective overburden pressure), is the only unusual characteristic of the Site 646 porosity profile (Fig. 10). The disappearance of siliceous microfossils and increase in calcareous microfossils at this depth are apparently responsible for the change in porosity. No other distinct changes in sediment composition or texture are present at this depth.

Unusual features of the porosity profile at Site 647 include high porosity of siliceous sediments of the middle segment of the profile, (lithologic Unit II, Subunits IIIA and IIIB) and a high porosity-pressure gradient in the top interval (lithologic Unit I). Although porosities are high in Unit II and Subunits IIIA and IIIB, especially considering porosities of sediments at equivalent pressures at Sites 645 and 646 (Fig. 10), similar highporosity siliceous sediments at comparable sub-bottom depths have been documented at Deep Sea Drilling Project (DSDP) sites in the equatorial Pacific (Keller and Bennett, 1973; Mayer, 1982), Bering Sea (Lee, 1973), and Norwegian Sea (Talwani, Udintsev, et al., 1976). The high porosity of these sediments was attributed to the structural traits of siliceous microfossils that produce an open sediment framework.

Sediments of lithologic Unit I at Site 647 display a rate of porosity reduction with increasing overburden pressure higher than any other interval drilled during Leg 105 (Fig. 10). A porosity profile similar to that at Site 647 was documented for sediments of the Lofoten Basin of the Norwegian Sea at DSDP Site 345 (Fig. 11). The sedimentary section at Site 345 is grossly similar to that at Site 647. There are three lithologic units at Site 345: an upper unit of muds and sandy muds, a middle unit of terrigenous muds and diatomaceous muds, and a lower unit of muds and sandstones. The diatomaceous muds display the highest porosity at the site, and the lithologic unit above the diatomaceous muds displays a sharp decrease in porosity with in- 


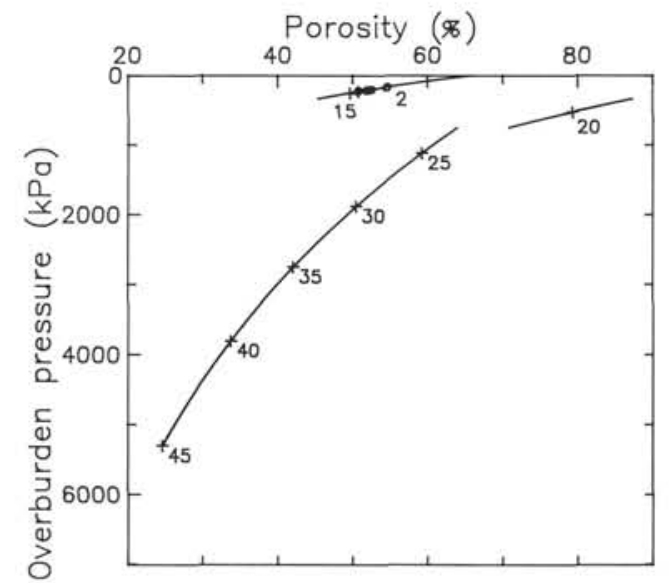

Figure 11. Porosity (rebound-corrected) vs. effective overburden pressure for DSDP Site 345, Norwegian Sea. Sediment ages at corresponding overburden pressures are indicated by circles ( $2 \mathrm{~m} . \mathrm{y}$. intervals) and crosses ( 5 m.y. intervals over $10 \mathrm{Ma}$ ). Coefficients for equations for the lines are listed in Table 1. The profiles are derived from density, porosity, and age data of Talwani, Udintsev, et al. (1976).

creasing pressure (Fig. 11). At both Sites 345 and 647, the decrease in porosity is so rapid in the unit overlying the biogenic silica-rich sediments that sediments at the base of the upper unit are more compacted than those at the top of the lithologic unit below the silica-rich interval. Based on similarities between the two sites, two hypotheses are proposed for the origin of the steep porosity-pressure gradients in the uppermost lithologic units at Sites 647 and 345 . The first hypothesis depends on the relative permeabilities of the siliceous sediments and the overlying terrigenous sediments. Although permeability does not strictly depend on porosity, there is a general trend of increasing permeability with increasing porosity (Bryant et al., 1981). As a consequence of this relationship, the intervals rich in siliceous microfossils are likely to be more permeable than the overlying finegrained terrigenous sediments. The permeability contrast may produce a drainage condition at the top and bottom of the uppermost units at Sites 647 and 345, which would cause a more rapid rate of dewatering (Lambe and Whitman, 1979). Assuming that the sediment response to an applied load is to compact until it reaches a porosity in equilibrium with that load (Engelhardt, 1977), the result of two-way drainage will only be a decrease in the time required to reach the equilibrium porosity. The magnitude of the ultimate effective overburden pressure will not be greater than that of more slowly consolidating sediment, but reaching the maximum effective stress more rapidly should lead to a greater degree of porosity reduction by grain deformation and other aging mechanisms. The second hypothesis for the origin of the steep porosity gradient in the top interval at Site 647 is related to chemical interactions with the underlying siliceous sediments. Diffusion of silica from the underlying biogenic clays may lead to porosity reduction in overlying sediments through the precipitation of authigenic minerals.

Variations in clay mineralogy and sedimentation rates also significantly affect compaction patterns at low overburden pressures (Meade, 1966; Engelhardt, 1977). The influence of clay mineralogy was not evaluated because the data were not available. Apparently, the sedimentation rate is not as influential as sediment texture. Near-surface sediments at Site 645 were deposited more rapidly than sediments at Sites 646 and 647 (Fig. 9), yet they display the lowest initial porosity. Higher sedimentation rates at Site 646 than at Site 647 may partially explain the higher porosity of near-surface sediments at the former site.

At effective overburden pressures greater than $3000 \mathrm{kPa}$, there are fewer differences in the porosity profiles of Sites 645,646 , and 647 (Fig. 10). This fact is consistent with observations of Meade (1966) and Engelhardt (1977) that at greater depths, pressure exerts the primary control on sediment porosity, and the influence of factors such as sediment composition and texture diminishes.

Porosity profiles for Sites 645 and 646 nearly overlap for pressures greater than $3000 \mathrm{kPa}$ (Fig. 10). Correspondence of the two curves is interesting in that the sediments at Site 645 are coarser-grained than those at Site 646 (Figs. 2 and 3). An inverse relationship between porosity and grain size generally exists for near-surface sediments; however, with increasing overburden pressure, the rapid decrease in porosity of clays overtakes the slower compaction of sands, and the porosity-grain size relationship changes from inverse to direct (Meade, 1966). Meade estimated that this switch occurs at burial depths near 1 $\mathrm{km}$. The change in the relationship for Sites 645 and 646 occurs at approximately $3300 \mathrm{kPa}$ (Fig. 10), which is equivalent to depths of $330 \mathrm{mbsf}$ at Site 645 and $470 \mathrm{mbsf}$ at Site 646 . The organic-carbon content in lithologic Unit III at Site 645 (1\%-5\%) is higher than that in Unit II at Site $646(0-0.5 \%)$ (Srivastava, Arthur, et al., 1987) and partially accounts for the higher porosity at Site 645 , based on the direct relationship between organiccarbon content and porosity (Busch and Keller, 1981). The influence of sediment age on porosity differences between the two sites is insignificant. Sedimentation rates differ between sites, but because of the change from more rapid to slower rates at Site 645, ages of overlapping sections at Sites 645 and 646 are comparable (Fig. 10).

The lowermost segment of the Site 647 porosity profile, which encompasses lithologic Subunit IIIC and Unit IV, displays a higher porosity-pressure gradient than the lower intervals of Sites 645 and 646 (Fig. 10). This interval at Site 647 displays a higher calcium carbonate content $(29.6 \%$ average) than the lowermost intervals at Sites 645 (2.6\% average) and 646 (8.8\% average); however, a higher calcium carbonate content should result in a lower porosity gradient and higher overall porosity (Bryant et al., 1981), the opposite of the trends present at Site 647. The higher porosity-pressure gradient most likely reflects the greater age of sediments at Site 647 (Fig. 10). Over a longer period of time, the opportunity for porosity reduction by aging-related factors, such as grain deformation and cementation, increases. Evidence of diagenetic alteration can be seen in sediments of lithologic Unit IV. Features reflecting diagenetic activity in this unit, which overlies the basaltic basement, include iron-oxidebearing claystones, color banding, dolomite concretions, occasional chert and gypsum crystals, and hydrothermal and quartz veins. In addition, slickensided fractures or small faults are present in the sediments. Together, these chemical and physical features represent factors responsible for porosity reduction. The lowermost lithologic unit at Site 345 displays a rapid decrease in porosity with increasing overburden pressure similar to that at Site 647 (Fig. 11). This section is comparable in age to that at Site 647 and also rests on basaltic basement.

\section{Comparison with Reference Sections}

The extent to which compaction patterns at the Leg 105 sites are representative of terrigenous sediment sections and the validity of the correction for porosity rebound can be examined in a comparison with other Tertiary terrigenous-dominated sections deposited in undeformed marine basin settings. To facilitate this comparison, the rebound-corrected porosity profiles for the Leg 105 sites are transformed from porosity-pressure plots to porosity-depth diagrams (Fig. 12). Conversion to depthbased diagrams does alter the curves. Using the Site 646 porosity profile as a reference, transformation from a pressure to a depth scale shifts the Site 645 profile upward and the Site 647 profile downward. 


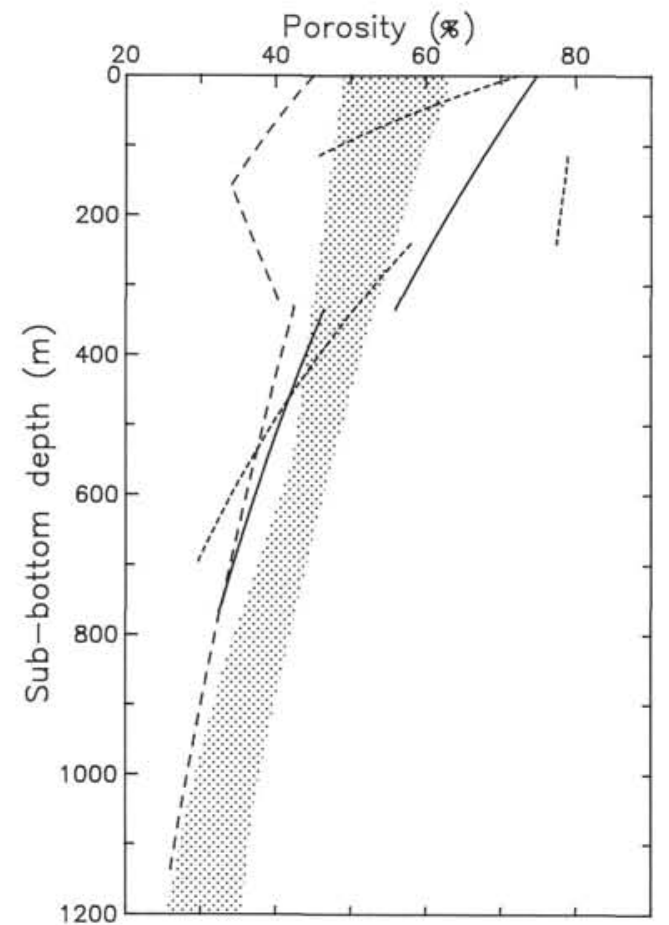

Figure 12. Porosity (rebound-corrected) vs. depth for Site 645 (long dashes), Site 646 (solid line), and 647 (short dashes). Coefficients of equations for lines are listed in Table 1 . Shaded area represents the range for seismic and in-situ log porosity profiles shown in Figure 13.

Figure 13 displays terrigenous-sediment, porosity-depth diagrams commonly cited in sediment-compaction studies (Meade, 1966; Rieke and Chilingarian, 1974; Hamilton, 1976; Bryant et al., 1981). The reference sections include profiles based on (1) sample porosities (Hedberg, 1936; Dickinson, 1953); (2) seismic and in-situ log porosities (Ham, 1966; Magara, 1968; Sclater and Christie, 1980); and (3) laboratory-determined porosities corrected for expansion (Hamilton, 1976). Obtaining reference sections for comparison is difficult. Borehole logs are infrequently run at shallow depths, and curves in this range, such as those in Magara (1968) above $250 \mathrm{mbsf}$, are extrapolations. Also, porosity data from land-based oil wells, such as those of Hedberg (1936), are too low at shallow depths and cannot be compared to seafloor sediments (Hamilton, 1976).

Comparison of porosity profiles at Sites 645,646 , and 647 (Fig. 12) with those of the reference sections (Fig. 13) illustrates the wide range of porosities in the Baffin Bay and Labrador Sea sediments at depths less than 350 mbsf. At Sites 646 and 647 , the porosity of near-surface sediments is near that of the Arabian Sea section (DSDP Site 222) that Hamilton (1976) selected to represent typical terrigenous deep-sea sediments. The porosity-depth gradient in the top interval at Site 646 is approximately equal to that at Site 222 over the same depth range, but the porosity magnitude is $3 \%$ to $7 \%$ higher at the Labrador Sea site, which possibly reflects the influence of siliceous microfossils. Rapid decrease in porosity immediately below the seafloor at Site 647 roughly parallels the porosity decrease documented by Dickinson (1953) for continental margin sediments of the northwestern Gulf of Mexico. Pleistocene and Pliocene sediments encompassed by Dickinson's profile are interbedded muds and sands (Martin, 1978), and drainage provided by the sands may explain the rapid porosity reduction in his profile. Porosities for the entire upper interval at Site 646 and the initial portion of the top segment of the Site 647 profile are greater than

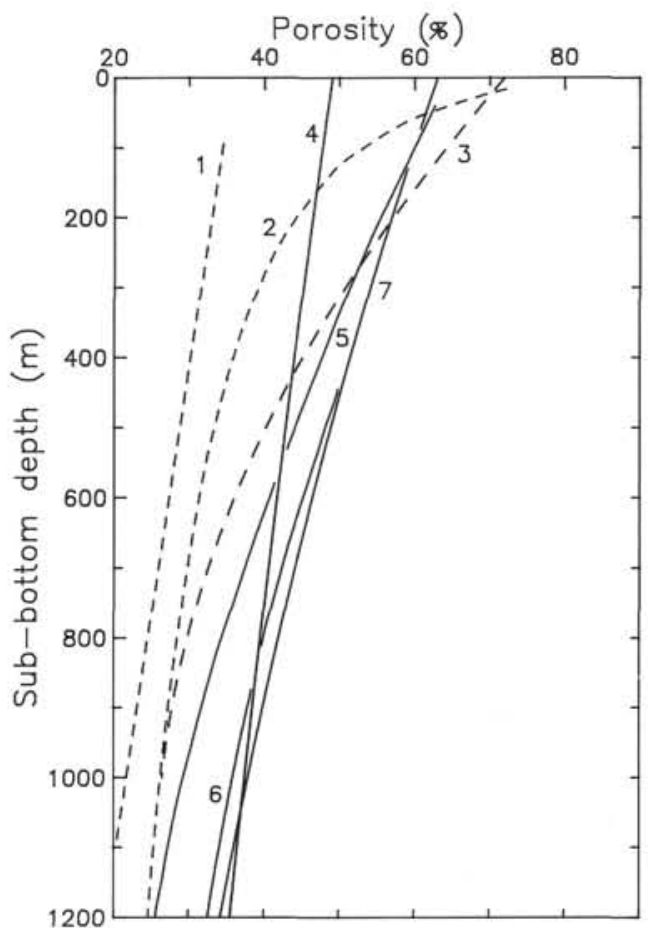

Figure 13. Porosity vs. depth for Tertiary terrigenous sediment reference sections. Solid lines are seismic and in-situ log porosity profiles. Dashed lines represent profiles based on laboratory-measured porosities. Only that portion of the reference sections that corresponds to the maximum sediment thickness drilled during Leg 105 is shown. 1. Venezuela (Hedberg, 1936). 2. Gulf of Mexico (Dickinson, 1953). 3. DSDP Site 222, Arabian Sea, corrected for porosity rebound (Hamilton, 1976). 4. North Sea, composite sandstone profile (Sclater and Christie, 1980). 5. Shiunji gas field, Nagaoka Plain, Japan (Magara, 1968). 6. Gulf Coast (Gulf of Mexico) composite shale (Ham, 1966). 7. North Sea, composite shale (Sclater and Christie, 1980).

the range of in-situ log porosities (Fig. 12). This difference most likely reflects the difficulty of obtaining logs in this depth range.

Shallow sediments at Site 645 display lower porosities than all of the profiles shown in Figure 13, except the Venezuela composite of Hedberg (1936), which because of its land-based origin may not be strictly comparable. The in-situ log reference section nearest to that of Site 645 is the North Sea sandstone composite profile (Sclater and Christie, 1980), which supports the interpretation that coarse grain size is responsible for low porosity at Site 645 .

Comparison of the deeper parts of the porosity profiles may have greater significance. Lithologic and depositional controls are less influential on porosity at greater depths, in-situ logs are more readily available, and data from oil fields on land are more comparable to marine sections. Because of these factors, the validity of the expansion correction for laboratory-measured porosity is more easily evaluated in this depth range.

At depths greater than $350 \mathrm{mbsf}$, the Leg 105 profiles correspond more closely to the reference sections (Figs. 12 and 13). The lower intervals of porosity profiles for Sites 645 and 646 are nearly parallel to the reference profiles. The lowermost segment of the Site 647 profile shows the greatest divergence from the trends of the reference profiles. This segment differs from the other sections in that it directly overlies crystalline basement and contains evidence of associated diagenetic alteration that has reduced porosity.

Although the lower intervals of the Site 645 and 646 profiles parallel the trend of the reference sections, the porosities in 
these intervals are less than the range for the in-situ log profiles (Fig. 12). The reference profile nearest those of Sites 645 and 646 is the section at Site 222, which is also based on laboratory measurements corrected for expansion (Hamilton, 1976). The number of in-situ log profiles shown in Figure 13 is limited, and differences between the range of these profiles and the profiles at Sites 645, 646, and 222 may reflect differences in lithology or other factors. Core-based profiles of Hedberg (1936) and Dickinson (1953), which are not corrected for porosity rebound, are even farther removed from the seismic and in-situ log range than are the Sites 645, 646, and 222 profiles (Fig. 13). This difference suggests that a greater range might be expected if more in-situ data were available. It is also possible that the rebound-corrected porosities are lower than the in-situ profile range as a consequence of the correction technique of Hamilton (1976) overcompensating for expansion. The close match of the corrected porosity profile with the profile of porosity estimated from the sonic log at Site 646 (Fig. 8) attests to the soundness of Hamilton's method for expansion correction, at least at this site. The accuracy of the expansion correction for other sites cannot be determined.

\section{SUMMARY}

Sediments cored at Site 645 in Baffin Bay and at Sites 646 and 647 in the Labrador Sea are predominantly terrigenous sediments having lesser and variable proportions of biogenic material. Compaction patterns at the three sites were examined using data from shipboard density and porosity determinations for core samples. In-situ porosities at these sites were estimated from the sample porosity data by applying a correction for sediment expansion. This correction provides a particularly good porosity estimate at Site 646 . At this site, the borehole sonic log provides a second estimate of in-situ porosities that is nearly identical to the corrected porosities measured in the laboratory. Comparison of corrected porosity profiles for Sites 645,646 , and 647 reveals that the greatest variability among these sites and between the Leg 105 sites and other Tertiary terrigenous sections is at depths less than $350 \mathrm{mbsf}$. Origin of the more variable compaction patterns in this depth range comes from sediment texture and composition control on the initial porosity and subsequent rate of dewatering. The higher percentage of sand in sediments at Site 645 contributes to the low porosity at this site. High concentrations of siliceous microfossils are responsible for high porosities observed at Site 647 and, to a lesser extent, at Site 646. Rapid porosity reduction in the uppermost unit at Site 647 is linked to the underlying siliceous sediments through twoway drainage of the overlying unit or upward diffusion of silica. At greater depths, pressure is the dominant influence on compaction patterns. Porosity profiles at Sites 645 and 646 are similar below $350 \mathrm{mbsf}$ and parallel the trend of reference terrigenous sediment profiles. Greater sediment age and more extensive diagenetic alteration of sediments in the lower part of Site 647 are responsible for a high porosity-pressure gradient in this interval.

\section{ACKNOWLEDGMENTS}

I thank K. Dadey, who shared the responsibility of collecting the shipboard density and porosity data, and R. Jarrard, who provided the borehole data from Site 646. I also thank H. J. Lee and R. W. Faas for critical reviews of the manuscript. This study was supported by funds from the National Science Foundation and the Joint Oceanographic Institutions, administered through the U.S. Science Program associated with the Ocean Drilling Program.

\section{REFERENCES}

Addis, M. A., and Jones, M. E., 1985. Volume changes during diagenesis. Marine Pet. Geol., 2:241-246.

Athy, L. F., 1930. Density, porosity, and compaction of sedimentary rocks. AAPG Bull., 14:1-24.
Berner, R. A., 1980. Early Diagenesis, A Theoretical Approach: Princeton (Princeton University Press).

Boyce, R. E., 1976. Definitions and laboratory techniques of the compressional sound velocity parameters and wet-water content, wet bulk density, and porosity parameters by gravimetric and gamma ray attenuation techniques. In Schlanger, S. O., Jackson, E. D., et al., Init. Repts. DSDP, 33: Washington (U.S. Govt. Printing Office), $1115-1128$.

Bryant, W. R., Bennett, R. H., and Katherman, C. E., 1981. Shear strength, consolidation, porosity and permeability of oceanic sediments. In Emiliani, C. (Ed.) The Oceanic Lithosphere, The Sea (Vol. 7): New York (Wiley), 1555-1616.

Busch, W. H., and Keller, G. H., 1981. The physical properties of PeruChile continental margin sediments-the influence of coastal upwelling on sediment properties. J. Sediment. Petrol., 51:705-719.

Dickinson, G., 1953. Geological aspects of abnormal reservoir pressures in Gulf Coast Louisiana. AAPG Bull., 37:410-432.

Engelhardt, W. V., 1977. The Origin of Sediments and Sedimentary Rocks: New York (Halstead Press).

Ham, H. H., 1966. New charts help estimate formation pressure. Oil \& Gas J., 64:58-63.

Hamilton, E. L., 1971. Prediction of in situ acoustic and elastic properties in marine sediments. Geophysics, 36:266-284.

1974. Prediction of deep-sea sediment properties: state of the art. In Interbitzen, A. L. (Ed.), Deep Sea Sediments: Physical and Mechanical Properties: New York (Plenum Press), 1-43. 1976. Variations of density and porosity with depth in deepsea sediments. J. Sediment. Petrol., 46:280-300. , 1978. Sound velocity-density relations in sea-floor sediments and rocks. J. Acoust. Soc. Am., 63:366-377.

Hedberg, H. D., 1936. Gravitational compaction of clays and shales. Am. J. Sci., Fifth Ser., 31:241-287.

Keller, G. H., and Bennett, R. H., 1973. Sediment mass physical properties - Panama Basin and northeastern Equatorial Pacific. In van Andel, Tj. H., Heath, G. R., et al., Init. Repts. DSDP, 16: Washington (U.S. Govt. Printing Office), 499-512.

Korvin, G., 1984. Shale compaction and statistical physics. Geophys. J. Roy. Astr. Soc., 78:35-50.

Lambe, T. W., and Whitman, R. V., 1979. Soil Mechanics: New York (Wiley).

Lee, H. J., 1973. Measurements and estimates of engineering and other physical properties, Leg 19. In Scholl, D. W. Creager, J. S., et al., Init. Repts. DSDP, 19: Washington (U.S. Govt. Printing Office), 701-719.

Magara, K., 1968. Compaction and migration of fluids in Miocene mudstone, Nagaoka Plain, Japan. AAPG Bull., 52:2466-2501.

, 1976. Water expulsion from clastic sediments during compaction - directions and volumes. AAPG Bull., 60:543-553.

Martin, R. G., 1978. Northern and eastern Gulf of Mexico continental margin: stratigraphic and structural framework. In Bouma, A. H., Moore, G. T., and Coleman, J. M. (Eds.), Framework, Facies, and Oil Trapping Characteristics of the Upper Continental Margin: Tulsa (Am. Assoc. Pet. Geol.), 21-42.

Mayer, L. A., 1982. Physical properties of sediment recovered on Deep Sea Drilling Project Leg 68 with the hydraulic piston corer. In Prell, W. L., Gardner, J. V., et al., Init. Repts. DSDP, 68: Washington (U.S. Govt. Printing Office), 365-382.

Meade, R. H., 1966. Factors influencing the early stages of the compaction of clays and sands-review. J. Sediment. Petrol., 36:1085-1101.

Rieke, H. H., III, and Chilingarian, G. V., 1974. Compaction of Argillaceous Sediments: Amsterdam (Elsevier).

Sclater, J. G., and Christie, P.A.F., 1980. Continental stretching: an explanation of the post-mid-Cretaceous subsidence of the central North Sea Basin. J. Geophys, Res., 85:3711-3739.

Skempton, A. W., 1970. The consolidation of clays by gravitational compaction. J. Geol. Soc. London, 125:373-412.

Srivastava, S. P., Arthur, M., et al., 1987. Proc. ODP, Init. Repts., 105: College Station, TX (Ocean Drilling Program).

Talwani, M., and Udintsev, G., et al., 1976. Init. Repts. DSDP, 36: Washington (U.S. Govt. Printing Office).

Date of initial receipt: 15 July 1987

Date of acceptance: 14 October 1988

Ms 105B-143 